\title{
Spontaneous bacterial peritonitis by Clostridium species and antimicrobial therapy
}

\author{
Waseem Amjad ${ }^{1}$, Abu Hurairah², Ali Umair Farooq ${ }^{3}$ \\ ${ }^{1}$ Department of Medicine, Northwell-Long Island Jewish Forest Hills Hospital, New York, USA \\ 2Division of Gastroenterology, SUNY Downstate Medical Centre, New York, USA \\ ${ }^{3}$ Charleston Area Medical Centre, Charleston, West Virginia, USA
}

Gastroenterology Rev 2017; 12 (4): 313-314

DOI: https://doi.org/10.5114/pg.2017.72110

Address for correspondence: Waseem Amjad MD, Department of Medicine, Northwell-Long Island Jewish Forest Hills Hospital, 102-01 66 ${ }^{\text {th }}$ Road, Forest Hills, 11375 New York, USA, phone: +1 9292457724, e-mail: waseemonline001@gmail.com

Spontaneous bacterial peritonitis (SBP) is common in decompensated cirrhosis. Its incidence is $10-30 \%$ in patients with ascites and chronic liver disease. Mortality is almost $25 \%$ in patients with SBP [1, 2]. We are presenting a very rare case of SBP secondary to clostridium species.

A 65-year-old man known to have chronic hepatitis C (treatment naive), poly-substance abuse, Child-Pugh $C$ cirrhosis, and gastroesophageal reflux disease (on chronic acid suppression) was admitted due to fever and generalised abdominal pain for 3 days. He had a history of paracentesis three times in the past. He was on ciprofloxacin 500 mg twice daily maintenance because of previous SBP (culture negative neurocytic ascites) for 1 month. Vitals were normal except fever of $101 \mathrm{~F}$. On general physical examination, the patient was cachectic, lethargic, had scleral icterus, gynaecomastia, and spider angiomata on the chest; the abdomen was distended and tender, with dilated veins radiating from the umbilicus. Pulmonary, cardiovascular, and neurological examinations were unremarkable.

Labs showed white blood cells (WBCs) of $12.6 \times$ $10^{9}$ cells/l, total bilirubin $4.6 \mathrm{mg} / \mathrm{dl}$, international normalised ratio (INR) was 1.67 , and serum albumin was $26 \mathrm{~g} / \mathrm{l}$. Paracentesis was done and 5.6 I fluid was removed followed by administration of $37.5 \mathrm{~g}$ of albumin in three divided doses, fluid analysis showed polymorphonuclear count (PMN) of 12,996 cells $/ \mathrm{mm}^{3}$, ascitic fluid albumin of $12 \mathrm{~g} / \mathrm{l}$, and glucose of $58 \mathrm{mg} / \mathrm{dl}(3.2 \mathrm{mmol} / \mathrm{l})$. Ultrasound showed large abdominal ascites, the liver was small, and there was some hepatofugal flow in the main portal vein (Figure 1). Computed tomography (CT) scan of the abdomen revealed massive abdominal and pelvic ascites with a shrunken liver with a nodular undulating contour consistent with liver cirrhosis, spleno- megaly was appreciated, and no bowel pathology was noticed (Figure 2).

Intravenous cefotaxime 2 g every 8 h was started empirically, and the ascitic fluid culture was positive for clostridium species (unspecified microbiologically) in two bottles. Blood cultures were negative for bacteraemia. Stool assay was negative for Clostridium difficile. Intravenous metronidazole $500 \mathrm{mg}$ every $8 \mathrm{~h}$ was added. The patient improved clinically on the third day after addition of metronidazole. Repeat paracentesis was done on the fifth day and 1.1 I of ascitic fluid was drained. Fluid analysis revealed a significant decrease in PMN count to 190 cells $/ \mathrm{mm}^{3}$ and repeat ascetic fluid cultures were negative. The patient clinically improved and was discharged on the seventh day on oral metronidazole $500 \mathrm{mg}$ three times a day for 7 more days. Maintenance ciprofloxacin was continued for SBP prophylaxis.

Ascitic fluid with polymorphonuclear cells (PMN cells) more than 250 cells $/ \mathrm{mm}^{3}$ is called SBT [3]. Common microorganisms causing SBP are Gram-negative bacteria including Escherichia coli, Klebsiella species, and Enterobacter species. Gram-positive organisms are involved in $20 \%$ of cases and anaerobes in $3 \%$ of cases. Risk factors for Gram-positive and multidrug-resistant bacteria are recent hospitalisation, invasive procedures, and quinolone prophylaxis. The mechanism includes immune dysfunction due to portosystemic shunting, decreased phagocytic activity, and genetic polymorphism of toll-like receptor and nucleotide-binding oligomerisation domain 2 (NOD2) leading to bacterial translocation (BT).

Extraintestinal migration of bacteria or bacterial product can lead to SBP [4]. Ours is a very rare case of $\mathrm{SBP}$ due to clostridium species. Anaerobes rarely cause 


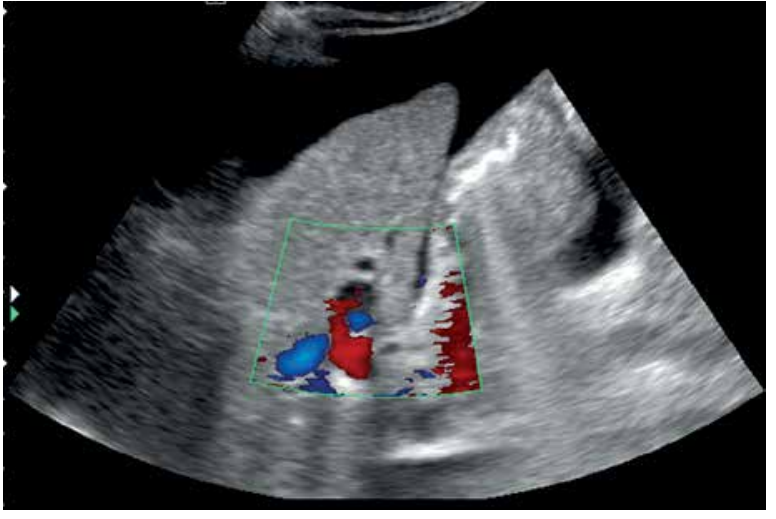

Figure 1. Ultrasound abdomen shows small liver and hepatofugal flow in the portal vein

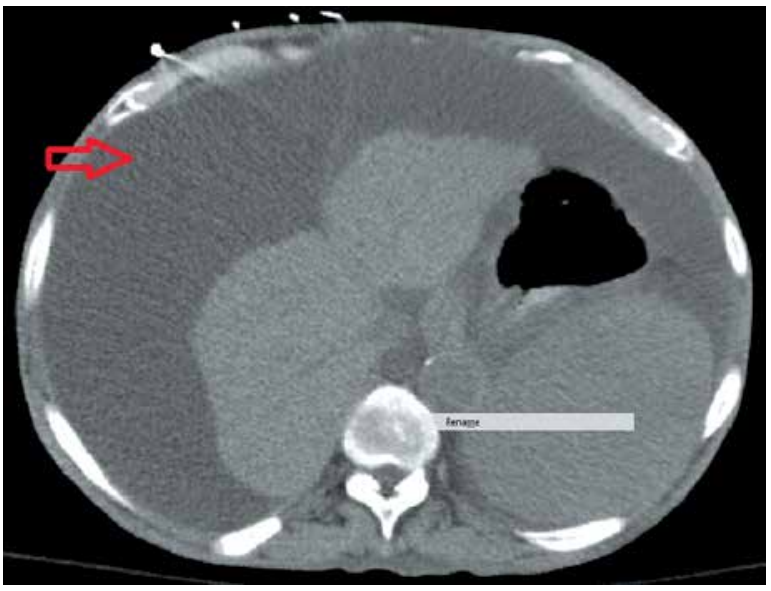

Figure 2. Computed tomography abdomen axial view showing large ascites (red arrow) and shrunken liver

SBP although they are predominant in the small intestine and colon, probably because of high oxygen tension of the ascetic fluid and relative inability to cross intestinal mucosa. Achlorhydria and decreased intestinal motility cause small intestinal bacteria overgrowth, which can cause SBP by bacterial translocation [5].

Spontaneous bacterial peritonitis usually presents with fever and abdominal pain. Diagnostic paracentesis should be performed earlyto avoid delayed diagnosis [6]. If the PMN cell count is greater than 250 cells $/ \mathrm{mm}^{3}$, empiric antibiotics should be started. Commonly used antibiotics are third-generation cephalosporins, amoxicillin-clavulanate, or quinolones.

In healthcare-associated SBP significant failure is noticed with the above antibiotics. A repeat diagnostic paracentesis should be done within $48 \mathrm{~h}$ of the start of treatment if clinical improvement is not appreciated [4].

Spontaneous bacterial peritonitis is associated with poor prognosis. Early paracentesis with fluid culture is recommended for a better outcome. In the absence of indication, excessive use of acid suppression in cirrhotic patients should be avoided.

\section{Conflict of interest}

The authors declare no conflict of interest.

\section{References}

1. Falcone M, Russo A, Pacini G, et al. Spontaneous bacterial peritonitis due to Methicillin-resistant Staphylococcus aureus in a patient with cirrhosis: the potential role for daptomycin and review of the literature. Infect Dis Rep 2015; 7: 6127.

2. de Mattos AA, Costabeber AM, Lionco LC, Tovo CV. Multi-resistant bacteria in spontaneous bacterial peritonitis: a new step in management? World J Gastroenterol 2014; 20: 14079-86.

3. Na SH, Kim EJ, Nam EY, et al. Comparison of clinical characteristics and outcomes of spontaneous bacterial peritonitis and culture negative neutrocytic ascites. Scand J Gastroenterol 2017; 52: 199-203.

4. Bunchorntavakul C, Chamroonkul N, Chavalitdhamrong D. Bacterial infections in cirrhosis: a critical review and practical guidance. World J Hepatol 2016; 8: 307-21.

5. Young PE, Dobhan RR, Schafer TW. Clostridium perfringens spontaneous bacterial peritonitis: report of a case and implications for management. Dig Dis Sci 2005; 50: 1124-6.

6. Runyon BA. Management of adult patients with ascites due to cirrhosis: an update. Hepatology 2009; 49: 2087-107.

Received: 4.05.2017

Accepted: 23.06.2017 